\title{
BACTERIAL CONSORTIA FOR RETTING OF COCONUT HUSKS IN TANKS
}

\author{
BY \\ Anita Das Ravindranath and Saroi Bhosle ${ }^{1}$
}

\begin{abstract}
A bacterial consortium developed on coconut husk leachates could ret coconut husk steeped for retting in rap water in a period of three months. The quality of the coir fibre obtained was comparable to traditionally retted fibre. The consortia could also bestow a greater degree of softness to the mechanically extracted coir fibre. Coir extraction can therefore be practiced by supplying the consortia for retting of husk for production of fibre and enhance the commercial utilization of the husk in coconut growing regions of Asia.
\end{abstract}

\section{INTRODUCTION}

"Coir" is a natural hard fibre which finds extensive application in the manufacture of mats, mourzouks, etc. It has also found end use as an appropriate geotextile material for preventing soll erosion on hill slopes and protecting rall, road and canal embankments. (Damodaran, A.D. et al 1995, Joseph, T.T. 1995). Coir fibre is extracted from the coconut husk either by "retting' or by mechanical extraction.

The ideal coir fibre which is the raw material for the manufacture of (Tood quality coir products is obtained by the retting process. This involves the bundling of coconut husks into lots of 5000-8000 and steeping them in saline backwaters for periods ranging between 6-11 months. During this period the husks are softened arid the binding matter holding the fibre together are degraded leading to the release of the fibre from its natural setting in the husk. (Heyn, A.N.J., 1951). The present work was carried out to study the effect of seedling of a consortium of bacteria on. coconut husks steeped for retting in tanks.

\section{MATERIALS AND METHODS}

\section{Preparation of the inoculum}

Eight litres of mineral salts medium was sterilised and 400 grams of mature husk cut into small pleces, surface sterilised with $0.1 \%$ mercuric chlorlde and added to the sterile medium @ 50 grams per litre. After incubation for 48 hours the leachate was transferred aseptically into sterile flasks arid inoculated with 5\% consortium. The flasks were incubated at 37 degrees for 24 hours and then used as inoculum for the experimental study on retting of husks/fibre.

\section{Retting of husks in tanks}

Three sets of laboratory rets using 100 litre carbuoys each containing 10 mature coconut husks were set up. Set A was treated with 47.5 litres of tap water arid 2.5 litres of the inoculum (5\%). Set B was treated with 45 litres of tap water arid 5 litres of inoculum. The treatment was repeated after 30 days of the first inoculation. Set $\mathrm{C}$ was treated with 50 litres of tap water arid retained as untreated control, The water in all the three sets were, changed at fortnightly intervals to simulate the flushing activity in the natural environment. The husks were drawn out after 90 days of steeping arid

\footnotetext{
${ }^{1}$ Central Coir Research Institute (Kalavoor) \& Goa University (Panayi), India, respectivelly.
} 
the fibre extracted by beating with wooden mallets. The extracted fibre was subjected to the Xenotest ${ }^{2}$ for assessment of lightfastness (Mukherjee, A.K. 1996).

\section{Retting of mechanically extracted coir fibre in the tanks}

Ten (10) kilograrns of machine extracted coir fibre was soaked in 25 litres of tap water in three carbuoys; Set X, Y and Z for seven (7) hours. The water in ail three tanks were drained out to rernove the very dark colured leachates and refilled. Tanks $X$ and $Y$ were inoculated with $5 \%$ and 1 $0 \%$ of the consortia and incubated for 48 hours. Tank $\mathrm{Z}$ was maintained as uninoculated control. After 48 hours the water in all the three tanks were drained out and the fibre air dried. Fifty samples of each treated and control fibre frorn X, Y and Z were tied up on a PVC rod to attain the form of a ring having a radius of $2.3 \mathrm{crns}$ and allowed to rernain for 24 hours. The rings were then tested on a Flexural Rigidity Test (Mukherjee, A.K. 1996) with and without load and the defortnation in loading determined. The Flexural Rigidity was calculated using the following formula:

$$
\begin{aligned}
\text { Flexural Rigidity } & =0.0047 \mathrm{mg}(2 \pi \mathrm{r} 2) \cos \Theta / \tan \Theta \\
\text { where } \mathrm{Mg} & =\text { weight of load applied } \\
\mathrm{r} & =\text { radius of the ring } \\
\mathrm{d} & =\text { deformation of lower end of ring } \\
\Theta & =493 \mathrm{~d} / \mathrm{r} \pi \mathrm{r}
\end{aligned}
$$

\section{RESULTS AND DISCUSSION}

The progress in retting of the coconut husks in each set was monitored by drawing out husk samples at fortnightly intervals. The main criteria for judging the progress in retting, by observing the extent of softness of the husk and the ease in separation of the exocarp was noted manually. After 90 days it was observed that the husks in Set A and Set B could be peeled off without much effort indicating the completion of retting. However, the husks from Set $\mathrm{C}$ displayed incomplete retting as the husks were not as soft as that in Set a and B.

The ratings of lightfastness with the consortia treated. fibre is comparable to that of the fibre extracted by conventional methods. The leaching out of polyphenols from the coconut husks steeped for retting has been reported earlier (Jayasankar, N.P. \& Bhat, J.V. 1966) to be the main cause for the delay in the retting process. In the present study the organisms breakdown the polyphenols being from a consortia developed on husk leachates and then reduce the period of retting to three months.

Such studies have been tried in the natural retting environments using mixed phenol degrading strains of bacterial cultures on lots of coconut husks steeped for retting. Under such conditions also the retting period is observed to reduce from 9 to 3 months. (Das, A.R. \& Sarma U.S. 1995). This is the first study in which a consortium has been developed by repeated subcultures on coconut husk leachates and applied on husks and fibre.

The mechanically extracted fibre on treatment with the consortia also showed greater degree of softness after a period of 72 hours with the Flexural Rigidity Test (Table 2). The present work indicates that the application of such a consortia can enable production of coir by retting of coconut husks/mechanically extracted fibre in tanks. This would lead to the economic utilisation of the husk potential available in coconut growing regions of the world.

\footnotetext{
${ }^{2}$ Xenotest is a uniform specification for rating the light and weather fastness of dyed and non dyed materials. This tests helps in determining the same more quick-ly than it is in nature. It has a 1,500 $\mathrm{W}$ xenon are lamp as a source of radiation, the filtered spectrum of this lamp when used in the Xenotest is the same as sunfight. The samples are subjected to aftemate periods of light and dark. This simulates conditions of day and night approximately. A test time of 24 hours in the Xenotest is roughly equivalent to the radiation received over 10 days in the open air averaged throughout the year. (Mukherjee. A.K. 1996).
} 
Table 1: Lightfastness Studies

Test Method Exposure to xenon arc lamp quarzIampen geselischaft M.B.H. Hanau FRG.

Humidity $\quad 70 \%$

Temperature 37 degrees

Test $\quad 1006: 1955$

\begin{tabular}{|c|l|c|}
\hline Sample & \multicolumn{1}{|c|}{ Description } & Grade* $^{*}$ \\
\hline A & Fibre from $5 \%$ consortium Treated husk & 22 \\
\hline B & Fibre from $10 \%$ consortium Treated husk & 2 \\
\hline C & Fibre from control & 1 \\
\hline D & Fibre from tradionally Retted husk & 2 \\
\hline
\end{tabular}

Grade 1 - Fading within 80 minutes of test exposure

Grade 2 - Faring within 145 minutes of test exposure

Table 2: Flexural Rigidity Test

\begin{tabular}{|c|c|c|c|c|}
\hline Sample & Set 1 & Set 2 & Set 3 & Average (gems) \\
\hline $\mathrm{X}$ & 0.79 & 0.79 & 0.9 & 0.75 \\
\hline $\mathrm{Y}$ & 0.78 & 0.88 & 0.96 & 0.87 \\
\hline $\mathrm{Z}$ & 0.085 & 1.11 & 1.01 & 0.99 \\
\hline
\end{tabular}

\section{ACKNOWLEDGMENT}

Acknowledgments are due to Dr. U.S. Sarma, Director, RDTE Central Coir Research Institute for his encouragements on the subject of coconut husk retting. Acknowledgments are also due to Prof (Dr.) S. Mavinkurve, Head, Dept. of Microbiology, Goa University for her keen interest and encouragements on this subject. 


\section{REFERENCES}

Damodaran, A.D., Pavithran, C \& Warrier, K.G.K. 1995. Polycoir and lightweight bricks. Proceedings of the Seminar on Modernisation of Coir Industry. Feb 17-18. pp 109-113

Das, A.R. \& Sarma, U.S. 1995. Bioinoculants for Coir Retting CORD Vol. XI pp. 34-40

Das, A.R. 1991. Processing of Coir - A biological approach to retting of coconut husks. CORD Vol VII pp. 52-57

Heyn, A.N.J. 195 1. Studies on the microbiological retting process for the preparation of a hard fibre, and the influence of this process on the fibre

propertles. Verhand, Konink Ned. Akad. Weteschap., Afd. Natuurk. H. Reeks, Deel 48, No. 1

Jayasankar, N.P. \& Bhat, J.V. 1966. Antonie van Leeuwenhoek, Vol. 32 (1966) No. 2 pp. 124-134

Joseph, T.T. 1995. Coir Products - Modern Trends. Proceedings of the Seminar on Modernisation of Coir Industry. Feb. 17-18. pp. 159-161

Mukherjee, A.K. 1996. Report on the FAO-UN sponsored Project on Softening, Bleaching, Dyring and Printing of Coir. 